Resumen por el autor, Stacy R. Guild.

Un método de reconstrucción gráfica para el estudio del órgano de Corti.

La mayor parte de los inevestigadores han descrito las lesiones cocleares en documentos escritos acompañados de diagramas de secciones midmodiolares, estimando de modo aproximado la longitud relativa de las diversas lesiones, generalmente en términos de las partes aproximadas de las vueltas de espira, sin haber evaluado la longitud de dichas espiras. Una interpretación mejor de los resultados puede conseguirse por el método previo del autor, que consiste en representar el brgano de . Corti como una banda derecha con las longitudes relativas de las medias vueltas de espira aproximadas; pero puesto que el valor linear de las diversas partes de una estructura curva contenidas en secciones radiales, oblícuas y tangenciales varía, la localización de los extremos de las lesiones solo puede ser aproximada. El método de representación gráfica que el autor describe en el presente trabajo, evalúa directamente las longitudes aproximadas de todas las porciones del órgano de Corti en los cortes seriados. En papel rayado cada espacio representa un corte; se determinan los cortes limitantes de cada media vuelta de espira y se dibuja una serie de semicírculos uniendo los puntos así hallados. El resultado es una curva semejante a una espiral que permite aproximadamente las variaciones de los valores lineares de diferentes secciones. Esta es la línea basal para representar gráficamente los datos que se desee. Los tantos por ciento de error para las diferentes porciones, determinados para seis gráficas, van incluídos en el trabajo. Los datos más exactos obtenidos por este nuevo método pueden transportarse a gráficas rectas para facilitar la comparación de numerosas observaciones. Este método no solo susministra datos más exactos sino también (en el caso de ser adoptado por otros investigadores en este campo), permite poner en posesión de otros los resultados en una forma que facilita una comparación más exacta que hasta el presente ha sido posible.

Translation by José F. Nonidez

Cornell Medical College, New York 


\title{
A GRAPHIC RECONSTRUCTION METHOD FOR THE STUDY OF THE ORGAN OF CORTI
}

\author{
STACY R. GUILD \\ Department of Anatomy, University of Michigan \\ ONE CHART AND THREE FIGURES
}

Many papers recording the lesions found in the cochleæ of animals submitted to experimental injury by various sounds, both pure tones and detonations, have appeared in the last fifteen years. For the purposes of this communication it is unnecessary to review these, other than to mention a few of the authors. There have been several papers by Wittmaack ('07, '09, '18) and his co-workers; a series of very good works have appeared from Siebenmann's laboratory at Basel, those by Yoshii ('09), Hoessli ('12, '13), and Satoh ('17, on birds) being prominent; a long report by Hoshino ('17) on detonation injuries and more recently one by Guild ('19) on detonation injuries of exposed and protected ears. The above are only a part of the experimental soundinjury records which have appeared.

The value of these studies in the ultimate solution of the problem of the physiology of hearing is in direct ratio to the accuracy with which the position and extent of the observed lesions have been recorded; provided, of course, that the histologic technique is satisfactory. Most workers in this field have recorded their observations by individual written protocols for each animal, describing by text matter or drawings the nature of the lesions and indicating their extent and position by such very general terms as "upper part of the basal turn," "almost all of the second turn," or "lower half of third turn and upper part of second turn." Such records are, at best, very indefinite, as they make a comparison of extents of injured areas almost impossible, as will become evident later. No attempt is made in such reports to indicate the 
difference in length of the various turns, and it will appear later in this paper that only the very roughest of estimates could be made thus of the relative linear values of the different lesions. They do, of course, serve to indicate in a general way the relative positions of the various lesions in the cochlex, and have been of great value thus. The only attempts at graphic summaries of the results have been diagrams of midmodiolar sections with the tone designation or the name of the gun (Hoshino) affecting the general region indicated in the various levels of the cochlear duct shown in the section (fig. 1).

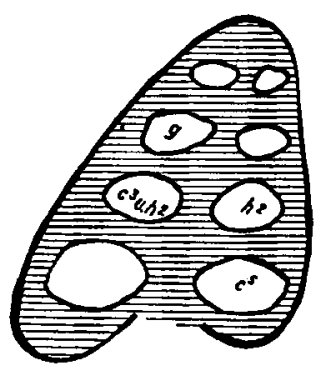

Fig. 1 Copy of a text figure in article by Yoshii ('09). This is an illustration of the method referred to in the text of diagrammatic localization of lesions with midmodiolar sections. It has been employed in connection with individual protocols and gives but a very rough idea of relative extents and positions of lesions.

While working on the problem of war deafness and the effectiveness of protective measures against detonation injuries, the writer recognized the need for a more accurate recording of the position and extent of the lesions and the desirability of having the data in a form which renders possible a more exact comparison of one record with another. While the method presented in the present communication was worked out then in its general features it was only partly made use of because of the need for haste at that time and the fact that the determination of the relative efficiencies of various forms of protection of the ears does not require the degree of accuracy in the location of the lesions that the work on the physiology of hearing requires. The relative lengths of 
the various half-turns of the organ of Corti of the animals used (guinea-pigs) were approximated by actual measurements of one cochlea, and the organ of Corti represented graphically by parallel spaces in charts, with the various half-turns marked off by vertical rulings. By shades of gray and other symbols, the nature of the lesions in the various parts of the different cochleæ was shown, but the positions of the ends of the areas injured were only approximations, although serial sections were used. The reason for this is self-evident when one recalls the continuous change in linear value of each section of the organ of Corti as it

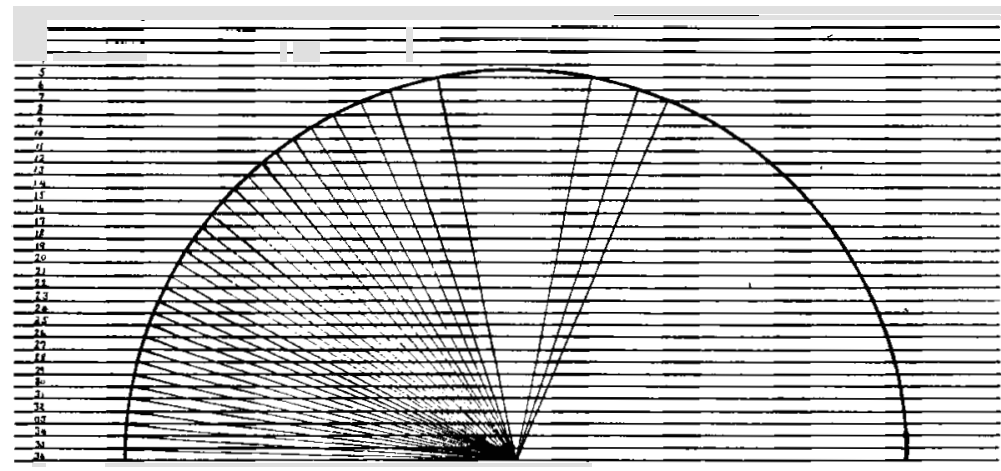

Fig. 2 Diagram to illustrate the changing linear value of the parts of a curved structure such as the organ of Corti included in sections of the same thickness. This diagram shows at a glance why the simple counting of the number of sections through which lesions pass gives but a very rough idea of the relative lengths.

passes from 'radial' to 'tangential' sections (fig. 2). A simple count of the number of sections does not give the relative lengths of any two parts of the given organ of Corti. But the method of recording used in that report (Guild, '19) permitted of a much better comparison of the lesions in various cochlex than would previous methods not only by the author, but by any one else interested. (Chart 1 is reproduced herefrom the author's previous publication to illustrate the method.)

The method of determination of the position and extent of lesions of the organ of Corti which will now be presented is one which the author believes will improve the accuracy of the state- 


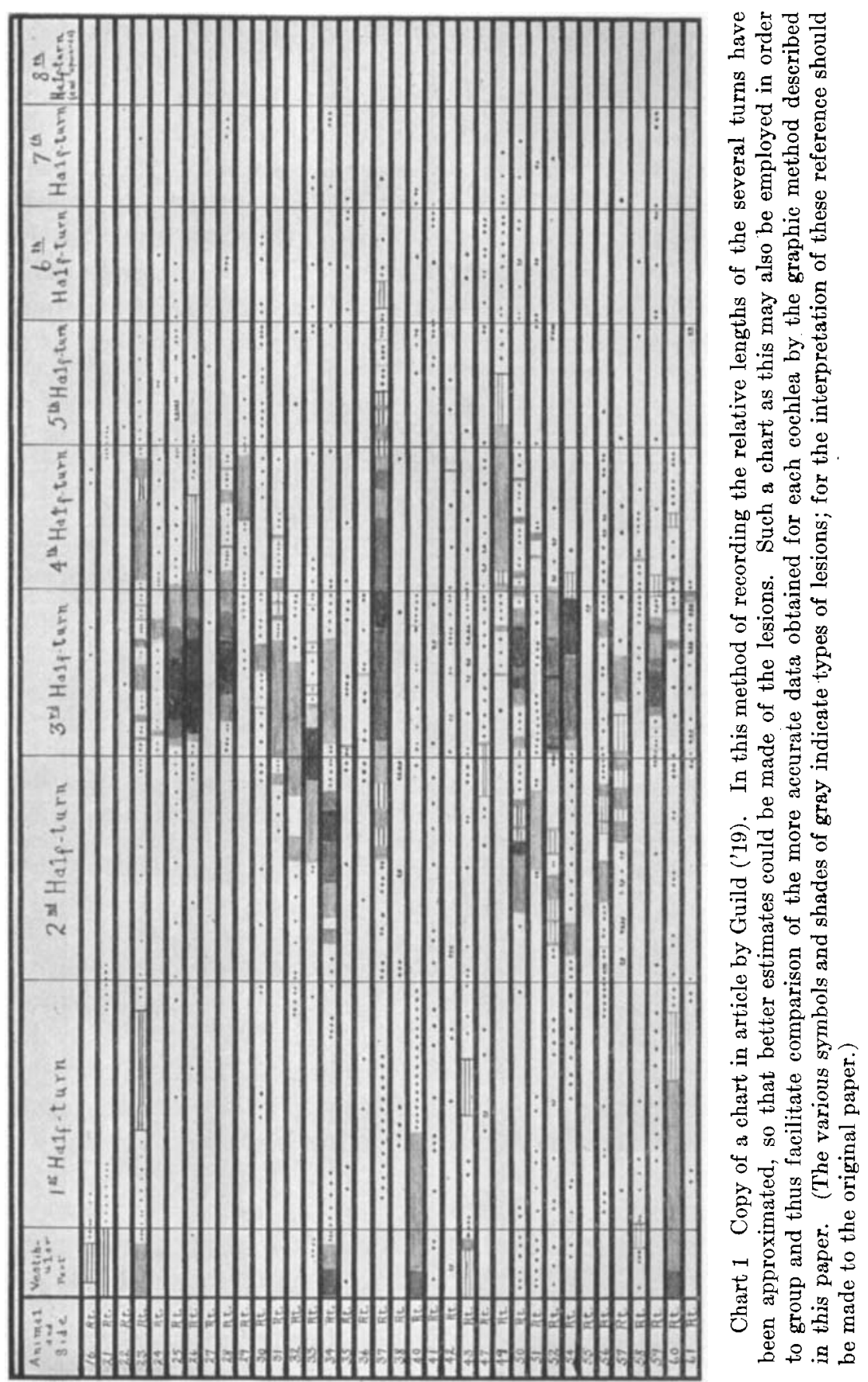


ments of location and relative extents of the injuries from various causes and which will, if adopted by other workers in this field, render the results of all available to the others in a form which will permit of ready comparison. This would, without question, be desirable and would facilitate the solution of the problem of the physiology of hearing.

\section{METHOD OF THE GRAPHIC RECONSTRUCTION}

Prerequisites to the use of the method are, 1) good fixation and embedding of the cochleæ, and, 2) serial sections of these cochleæ in the approximate plane of the modiolar axis. This is the planein which cochleæare most of ten cut for study. Loss of sections or lack of uniformity in thickness of the sections interferes with the use of this method, just as such imperfections render any reconstruction method unsatisfactory. The method most used by the author in preparing cochlear material has been fully described elsewhere (Guild '19). In brief, it consists of injection fixation with warm Zenker formalin solution followed by double embedding in celloidin and paraffin: most series have been cut at $7 \mu$; this, being about the thickness of the hair cells of the guinea-pig cochleæ, gives preparations which are better for most purposes than either thicker or thinner ones.

On closely ruled paper, such as that known as 'profile paper,' which has 400 spaces in a 20 inch width, each space is considered as representing a section, and a preliminary to starting a given reconstruction is the assigning of definite designations to as many spaces as there are sections involved in the part of the series to be plotted. The author has done this by actually writing the slide, row, and section number (in the row) in a column at the left end of the paper, rather than by designation by serial numbers of the total series of sections. This makes it very easy to identify corresponding sections and spaces at any time. With the guinea-pig cochleae cut at $7 \mu$, the basal turn of the organ of Corti (not the bony wall of the cochlea) usually extends over something more than 300 sections. As a 'base-line' the center of the union of the outer and inner pillar cells has been selected. The exact sections in which this union of the pillar cells is cut tangentially are deter- 

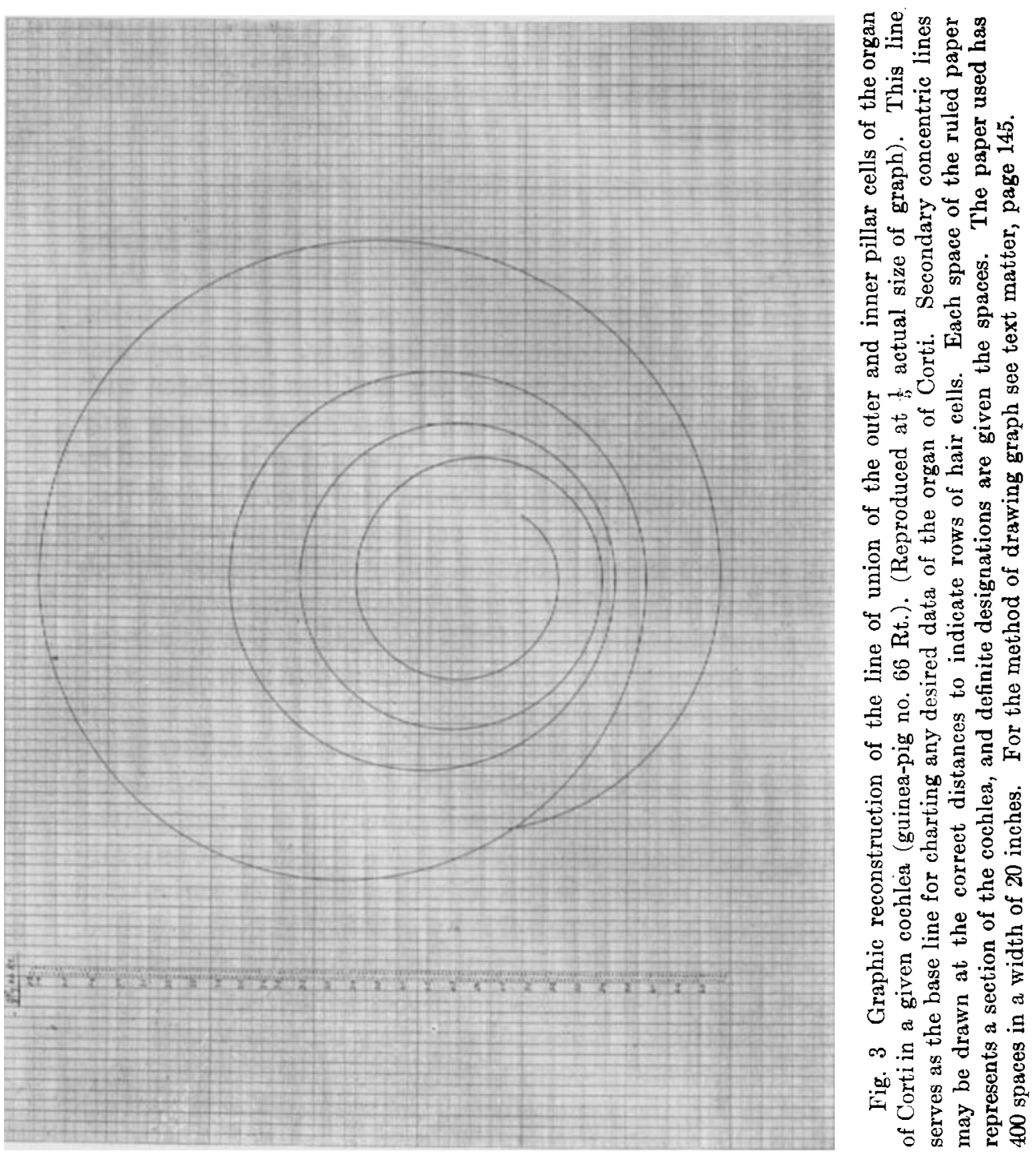
mined and indicated by marks in the correct spaces along a central line at right angles to the spaces representing sections. The tangential cuts of the organ of Corti are designated as the junction regions of the various 'half-turns' into which the cochlea may be considered as divided for descriptive purposes. Then the various marks representing the graphic positions of the half-turn junctions are connected by semicircles, each semicircle representing a half-turn of the cochlea; the centers of the semicircles are all on the common central line and the curvatures of successive circular arcs are such that there is no abrupt break evident to the eye. The graphic representation of the fractional turns beyond the last tangential cuts of the organ of Corti must be determined by a somewhat different method, since they end away from the centralline. For each end the procedure is the same: the section in which the last union of pillar cells occurs is found and the distance measured by the usual microscopic methods between this union and the union of pillar cells of the full half-turn continuous with it (being first half-turn for the basal end and eighth half-turn for the apical end in the guinea-pig). This distance is multiplied by the scale of the graph and then laid off along the space of the graph which represents the given section, one end being at the place where the line of the full half-turn concerned crosses the space, and the other end on the opposite side of the central line. This determines the position of the end of the fractional turn on the graph; the other end of this fractional turn is of course where the adjacent half-turn joins it at the central line. A circle is now determined which has its center on the central line and a radius such that the circumference passes through both of the above points, and an arc drawn ending at these points. The fractional turn at the basal end has been designated the 'vestibular part' and that at the apical end the 'apical part.'

The resulting 'base-line' is a continuous curved line somewhat like a spiral in general appearance, although far from it mathematically (fig. 3). The author fully realizes the sources of error introduced: among these are: 1) the change in curvature in the cochlea is probably continuous rather than abrupt; 2 ) the halfturns are not true semicircles, and 3) the fact that no allowance 
has been made for the 'basi-apical' distance traversed in the different parts. However, the author believes that a more exact approximation to a true graphic representation of length of the organ of Corti would involve so much mathematical calculation in the three dimensional determinations of points and their projections onto a plane surface that but few, if any, otological workers would have either time or facilities to carry out the procedure; whereas, the method here described requires only the use of microscope, drawing-board, ruled paper, and compasses, and is quickly done.

With such a base-line established, similar ' concentric' secondary lines may be drawn at the graphic distances of the various rows of hair cells, and the spaces between these concentric lines regarded as occupied by the hair cells. Then, in whatever order the serial sections are studied, the condition of the organ of Corti in each turn of each section, even to the individual hair cells, may be recorded by any suitable notation of colors or hatching. ${ }^{1}$ By this method the position and extent of the various lesions present are determined to a degree of accuracy hitherto not attained in the recording of such lesions, and to a degree which will permit much better correlation of the work by all interested in the problem of the physiology of hearing.

\section{CALCULATION OF ERRORS}

The writer has determined the approximate error of this method of reconstruction of the organ of Corti by the following means. The magnification at which any graph is made is determined by the ratio of the thickness of the sections of the series to the width of the spaces of the ruled paper. In any section in which two places of cutting of the union of the pillar cells are less than a halfturn apart the actual distance may be measured by the usual microscopic methods and compared with the distance on the graph between the places where the line representing the union of the

\footnotetext{
1 In order to avoid the confusion of the hatching lines by the rulings of the paper, the author plans to use tracing paper over the profile paper; this will make it much easier to disregard the section lines of the paper and yet permits them to be seen at any time for the determination of location.
} 
pillar cells crosses the space representing the given section. This is of course a comparison of the chords subtending the ares of the organ of Corti and of the graph rather than a comparison of the arcs themselves, but it seems reasonable to assume that the ratios of arcs and chords of these but slightly differing curves are such that the error introduced here is well within the limits of accuracy of the method in other respects. In order to determine the percentage value of the errors, the actual distance along a section was multiplied by the scale of the graph and this figure used as the denominator of a fraction of which the actual length along the corresponding space on the graph is the numerator. Evaluation of this fraction and the proper conversions give the result in the usual percentage terminology.

In order to determine the probable errors inherentin the method the writer has measured, by the procedures above described, the chords subtending the ares of the base-line in either each tenth or each fifteenth section in each turn of each of six reconstructions. In table 1 are shown the detailed figures for one series; and in table 2 are shown only the figures giving percentage of error found by each measurement in the six series. In these tabulations, in the listing of the figures for each turn, the order of the sections measured is always the same; the order being from the tangential toward the radial or modiolar sections. This arrangement of the data calls attention to an interesting fact: i.e., the change in percentage of error is usually a continuous one and the direction of this change in value, when arranged with tangential sections first, is usually from positive numbers toward negative numbers (plus toward minus) whether the zero point is crossed or not. So constant is this that after it was observed the finding of a number out of order raised a question of error in computation and a complete recalculation was made. As a result those that are out of this order in the tables have all been rechecked until the writer is certain that they are not errors in computations. It is entirely possible that this progressive change in the percentage of error in each turn is due in some way to the semicircle combinations used in plotting. 
TABLE 1

Figures on which are based the percentages of error for the parts of the graph of the right cochlea of guinea-pig no. 66 (see text matter, p. 148, for explanation)

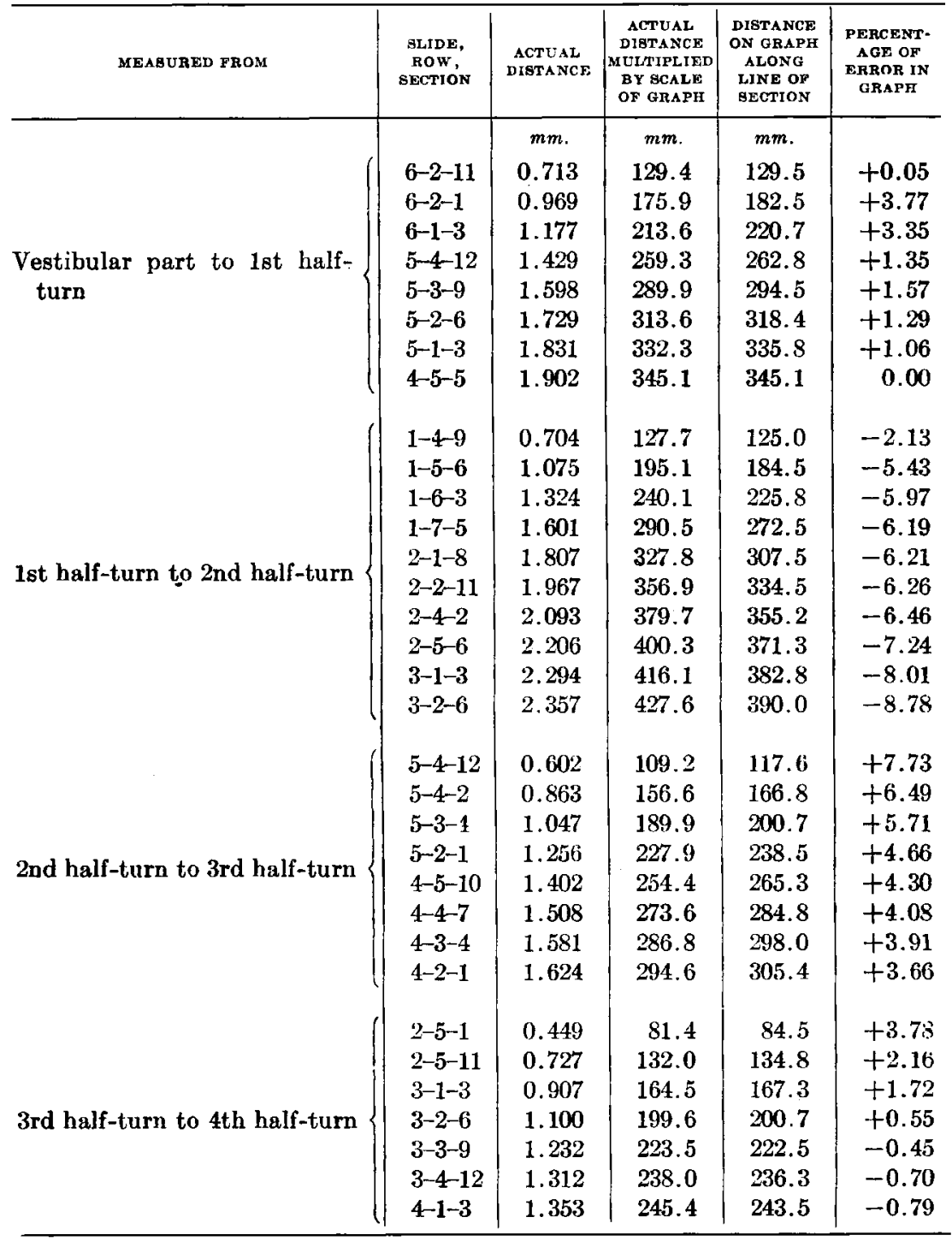




\begin{tabular}{|c|c|c|c|c|c|}
\hline MEASURED FROM & $\begin{array}{l}\text { BLIDE, } \\
\text { ROW, } \\
\text { BECTION }\end{array}$ & $\begin{array}{l}\text { ACTUAL } \\
\text { DIBTANCE }\end{array}$ & $\mid \begin{array}{c}\text { ACTOAL: } \\
\text { DIBTANCE } \\
\text { MULTIPLIED } \\
\text { BY GCALE } \\
\text { OF GRAPB }\end{array}$ & $\begin{array}{l}\text { DIETANCE } \\
\text { ON GBAPB } \\
\text { ALONG } \\
\text { LINE OF } \\
\text { SECTION }\end{array}$ & $\begin{array}{l}\text { PLRCENT- } \\
\text { AOE OF } \\
\text { TRROR IN } \\
\text { GRAPB }\end{array}$ \\
\hline 4th half-turn to 5 th half-turn & $\begin{array}{l}5-3-9 \\
5-2-11 \\
5-2-1 \\
4-5-10 \\
4-4-7 \\
4-3-4\end{array}$ & $\begin{array}{c}m m . \\
0.500 \\
0.727 \\
0.884 \\
1.039 \\
1.131 \\
1.199\end{array}$ & $\begin{array}{c}\mathrm{mm} . \\
90.7 \\
131.8 \\
160.3 \\
188.4 \\
205.2 \\
217.5\end{array}$ & $\begin{array}{c}\mathrm{mm} . \\
95.2 \\
134.8 \\
161.1 \\
187.7 \\
203.8 \\
211.8\end{array}$ & $\begin{array}{l}+4.96 \\
+2.23 \\
+0.48 \\
-0.38 \\
-0.67 \\
-2.63\end{array}$ \\
\hline 5th half-turn to 6 th half-turn & $\begin{array}{l}3-2-6 \\
3-3-4 \\
3-4-2 \\
3-5-5 \\
4-1-8 \\
4-2-11\end{array}$ & $\begin{array}{l}0.437 \\
0.662 \\
0.809 \\
0.954 \\
1.039 \\
1.086\end{array}$ & $\begin{array}{r}79.4 \\
120.1 \\
146.7 \\
173.1 \\
188.5 \\
197.0\end{array}$ & $\begin{array}{r}81.0 \\
120.8 \\
146.0 \\
170.2 \\
183.6 \\
188.5\end{array}$ & $\begin{array}{l}+2.08 \\
+0.64 \\
-0.49 \\
-1.68 \\
-2.61 \\
-4.31\end{array}$ \\
\hline 6th half-turn to 7 th half-turn & $\begin{array}{l}5-3-4 \\
5-2-6 \\
5-1-8 \\
4-5-5 \\
4-4-2\end{array}$ & $\begin{array}{l}0.438 \\
0.648 \\
0.779 \\
0.909 \\
0.972\end{array}$ & $\begin{array}{r}79.5 \\
117.5 \\
141.4 \\
165.0 \\
176.4\end{array}$ & $\begin{array}{r}78.9 \\
114.4 \\
136.5 \\
156.3 \\
165.5\end{array}$ & $\begin{array}{l}-0.79 \\
-2.67 \\
-3.47 \\
-5.28 \\
-6.16\end{array}$ \\
\hline 7th half-turn to 8th half-turn & $\begin{array}{l}3-4-7 \\
3-5-5 \\
4-1-3 \\
4-2-1 \\
4-2-11\end{array}$ & $\begin{array}{l}0.337 \\
0.545 \\
0.669 \\
0.743 \\
0.785\end{array}$ & $\begin{array}{r}61.2 \\
98.9 \\
121.3 \\
134.8 \\
142.5\end{array}$ & $\begin{array}{r}59.3 \\
95.5 \\
116.1 \\
128.2 \\
134.8\end{array}$ & $\begin{array}{l}-3.18 \\
-3.43 \\
-4.31 \\
-4.92 \\
-5.40\end{array}$ \\
\hline 8th half-turn to apical part & $\begin{array}{l}5-1-8 \\
5-1-3 \\
4-5-9\end{array}$ & $\begin{array}{l}0.302 \\
0.400 \\
0.484\end{array}$ & $\begin{array}{l}54.9 \\
72.5 \\
87.8\end{array}$ & $\begin{array}{l}58.6 \\
77.0 \\
87.8\end{array}$ & $\begin{array}{r}+6.83 \\
+6.20 \\
0.00\end{array}$ \\
\hline
\end{tabular}

In studying table 2 it is observed that the general nature of the differences between the measurements of the actual cochlear sections and of the graph for the corresponding turns of the several cochlex is the same. Thus, for the measurements between parts of the first and second half-turns the figures giving the percentage of error are in each case negative, and are larger in the modiolar region than any other figures for the same cochlea. This simply means that the true curvature of the basal turn differs 
TABLE 2

Percentayes of error as determined for each of six cochleae (see text matter, p. 149, and table 1 for explanation)

\begin{tabular}{|c|c|c|c|c|c|c|}
\hline & \multicolumn{6}{|c|}{ ANIMAL NUMBER AND BIDE } \\
\hline & $\begin{array}{l}64 \\
\text { Lefit }\end{array}$ & $\begin{array}{c}65 \\
\text { Right }\end{array}$ & $\begin{array}{c}86 \\
\text { Right }\end{array}$ & $\begin{array}{c}67 \\
\text { Right }\end{array}$ & $\begin{array}{c}68 \\
\text { Right }\end{array}$ & $\begin{array}{c}\text { 69 } \\
\text { Right }\end{array}$ \\
\hline \multirow{9}{*}{$\begin{array}{l}\text { Vestibular part to 1st } \\
\text { half-turn }\end{array}$} & per cent & per cent & per cent & per cent & per cent & per cent \\
\hline & +4.47 & -1.20 & +0.05 & +4.25 & -1.36 & +13.28 \\
\hline & +1.62 & -1.22 & +3.77 & +5.13 & -0.05 & +9. \\
\hline & +0.67 & -2.18 & +3.35 & +4.16 & +0.97 & +7.56 \\
\hline & +0.55 & -0.95 & +1.35 & +3.61 & +1.49 & +6.17 \\
\hline & +0.81 & -0.88 & +1.57 & +2.73 & +1.75 & +3.38 \\
\hline & +0.50 & -0.00 & +1.29 & +1.49 & +1.47 & +2.37 \\
\hline & 0.00 & -0.07 & +1.06 & 0.00 & +1.24 & 0.00 \\
\hline & & 00 & & & & \\
\hline \multirow{10}{*}{$\begin{array}{l}\text { 1st half-turn to } 2 \text { nd half- } \\
\text { turn }\end{array}$} & -4.62 & -2.40 & -2.13 & -8.01 & -10.76 & -10. \\
\hline & -5.13 & -3.77 & -5.43 & -9.38 & -10.21 & -11 \\
\hline & -6.29 & -5.08 & -5.97 & -9.17 & -9.78 & -11 \\
\hline & -6.47 & -5.04 & -6.19 & -9.74 & -9.71 & -11 \\
\hline & -6.99 & -5.36 & -6.21 & -10.32 & -9.03 & -11.65 \\
\hline & -7.05 & -5.52 & -6.26 & -10.71 & -9.18 & -12 \\
\hline & -7.76 & -5.58 & -6.46 & -11.49 & -9.70 & -13 \\
\hline & -8.39 & -6.80 & -7.24 & -11.87 & -10.41 & -14 \\
\hline & -8.62 & -7.44 & -8.01 & -13.12 & -10.87 & \\
\hline & -9.32 & & -8.78 & & & \\
\hline \multirow{8}{*}{$\begin{array}{l}\text { 2nd half-turn to } 3 \text { rd half- } \\
\text { turn }\end{array}$} & +6.23 & +6.92 & +7.73 & +7.85 & +1.90 & +4.87 \\
\hline & +5.54 & +4.08 & +6.49 & +5.75 & +2.05 & +4.57 \\
\hline & +4.38 & +4.56 & +5.71 & +3.98 & +2.02 & +2.6 \\
\hline & +4.01 & +4.28 & +4.66 & +3.73 & +1.92 & +2.2 \\
\hline & +3.65 & +3.18 & +4.30 & +3.29 & +1.58 & +2. \\
\hline & +3.32 & +2.65 & +4.08 & +2.75 & +1.49 & +2. \\
\hline & +3.00 & +2.94 & +3.91 & +2.47 & +1.36 & +1.3 \\
\hline & +2.33 & +2.81 & +3.66 & & & +1 \\
\hline \multirow{7}{*}{$\begin{array}{l}\text { 3rd half-turn to } 4 \text { th half- } \\
\text { turn }\end{array}$} & +1 & +4.39 & +3.78 & -0.62 & +4.42 & -3.08 \\
\hline & +0.17 & +3.02 & +2.16 & -0.88 & +2.06 & -1 \\
\hline & -0.57 & +1.51 & +1.72 & -0.58 & +0.11 & -1 \\
\hline & -0.88 & +1.34 & +0.55 & -1.26 & -0.34 & -2. \\
\hline & -1.31 & -0.30 & -0.45 & -1.86 & -0.73 & -2 \\
\hline & -1.81 & -0.92 & -0.70 & -2.43 & -0.79 & -3. \\
\hline & -2.93 & -1.92 & -0.79 & -3.74 & -1.49 & \\
\hline
\end{tabular}


TABLE 2-Continued

\begin{tabular}{|c|c|c|c|c|c|c|}
\hline & \multicolumn{6}{|c|}{ ANIMAL NUMBER AND SIDE } \\
\hline & $\begin{array}{c}\text { B4 } \\
\text { Left }\end{array}$ & $\begin{array}{c}65 \\
\text { Right }\end{array}$ & $\begin{array}{c}66 \\
\text { Right }\end{array}$ & $\begin{array}{l}67 \\
\text { Right }\end{array}$ & $\begin{array}{l}68 \\
\text { Right }\end{array}$ & Right \\
\hline \multirow{7}{*}{$\begin{array}{l}\text { 4th half-turn to 5th half- } \\
\text { turn }\end{array}$} & per cent & per cent & per cent & per cent & per cent & per cent \\
\hline & -0.50 & +4.17 & +4.96 & -1.97 & +2.66 & -0.38 \\
\hline & -1.25 & +1.46 & +2.23 & -3.69 & +0.86 & -0.34 \\
\hline & -2.22 & +0.23 & +0.48 & -3.22 & +0.70 & -0.28 \\
\hline & -2.97 & -0.60 & -0.38 & -3.70 & +0.50 & -0.68 \\
\hline & -3.28 & -0.82 & -0.67 & -3.92 & -0.75 & -0.97 \\
\hline & & & & $\begin{array}{r}-0.04 \\
-5.36\end{array}$ & & \\
\hline \multirow{6}{*}{$\begin{array}{l}\text { 5th half-turn to } 6 \text { th half- } \\
\text { turn }\end{array}$} & +0.91 & +2.88 & +2.08 & +2.27 & +3.00 & -1.87 \\
\hline & -0.47 & +0.21 & +0.64 & -1.76 & +0.76 & -2.56 \\
\hline & -1.64 & -1.22 & -0.49 & -2.31 & -0.44 & -3.21 \\
\hline & -1.88 & -2.30 & -1.68 & -3.52 & -1.58 & -3.42 \\
\hline & -2.65 & -3.34 & -2.61 & -4.40 & -2.85 & -3.94 \\
\hline & -3.63 & -5.71 & -4.31 & $\begin{array}{r}-5.51 \\
-6.37\end{array}$ & -3.78 & -4.98 \\
\hline \multirow{5}{*}{$\begin{array}{l}\text { 6th half-turn to } 7 \text { th half- } \\
\text { turn }\end{array}$} & -0.26 & +2.37 & -0.79 & -4.87 & +3.45 & +3.89 \\
\hline & -2.58 & +0.49 & -2.67 & -5.61 & -0.56 & -0.10 \\
\hline & -3.73 & -1.05 & -3.47 & -6.57 & -0.86 & -0.22 \\
\hline & -3.81 & -3.06 & -5.28 & -7.07 & -1.61 & -2.29 \\
\hline & -5.68 & -3.39 & -6.16 & -7.35 & -2.68 & -3.73 \\
\hline \multirow{5}{*}{$\begin{array}{l}\text { 7th half-turn to 8th half- } \\
\text { turn }\end{array}$} & -2.99 & +1.66 & -3.18 & -5.43 & +2.03 & +4.60 \\
\hline & -4.69 & -2.26 & -3.43 & -6.58 & -0.83 & +0.17 \\
\hline & -5.67 & -4.00 & -4.31 & -8.38 & -4.75 & -0.72 \\
\hline & -5.87 & -4.52 & -4.92 & -9.69 & -5.72 & -2.43 \\
\hline & -6.99 & & -5.40 & -10.89 & -7.92 & \\
\hline \multirow{3}{*}{$\begin{array}{l}\text { 8th half-turn to apical } \\
\text { part }\end{array}$} & & -0.33 & +6.83 & +7.04 & & +3.35 \\
\hline & & -1.34 & +6.20 & +2.99 & & -2.08 \\
\hline & & $\begin{array}{r}-0.38 \\
0.00\end{array}$ & 0.00 & 0.00 & & $\begin{array}{r}+1.39 \\
0.00\end{array}$ \\
\hline
\end{tabular}

more from a circular nature than any other part does, and that the degree of curvature is less than that of a circular arc of the dimensions of that determined by this graphic method. On the other hand, the figures for the second to third half-turns are in each case positive, and the percentage of error much less than for the first to second half-turns; this indicates that in this region the curvature 
of the organ of Corti deviated from the graph in the direction of having a slightly greater degree of curvature than the circular ares of the graph. In the remaining turns there is more variation in the individual cases, but the most common result is that of having the tangential sections with a positive error which grows less and crosses the zero point into negative values toward the modiolar sections.

In the actual use of the method in determining the extent and position of lesions in given cases, a correction factor could be determined and applied for the portions of the given cochlea, which ought to give values accurate enough to enable recognition of any numerical ratios favoring any of the theoretical requirements of the several theories of hearing.

\section{COCHLEAR VARIATIONS}

An interesting secondary result of the method is the demonstration of the amount of variation of individual cochleæ, both in total size and in relative proportions of the various parts. This is best brought out by tabulating the number of sections through which the various half-turns extend. Such a tabulation is given in table 3, the figures of the table being the number of sections from one tangential cut of the union of pillar cells of the organ of Corti to the next tangential cut of the same part; except for the vestibular part and the apical part, where the last ones are not cut tangentially. Variations in the orientation of the blocks for sectioning may be the cause for some of this, but the writer thinks that the orientation was too similar in the several series to account for very much of it; and, further, if this were the cause, the variation would be in the same direction for all turns, which it is not. Even the few cases recorded are sufficient to show that it is not at all correlated with the weight of the animals, the figures for which have been included in the tabulations. For instance, the smallest animal, weighing 225 grams, has a cochlea in which the distances between the several adjacent tangential cuts of the union of pillar cells are greater than for the corresponding turns of the largest animal, weighing 350 grams, and the variations are not uniform. 


\section{COMPARISON OF VARIOUS RECORDS}

To facilitate comparison of the lesions in a large number of cochlex, the positions and lengths determined by this method may be transferred to charts such as the author used in recording the lesions of the detonation deafness experiments. One of these is reproduced here as chart 1 for purposes of illustration. In such a chart the relative lengths given each half-turn are those of an

TABLE 3

Variation in individual cochleae. The figures show the number of $\gamma_{\mu}$ sections included in each turn (see text matter, p. 154, for parts measured)

\begin{tabular}{|c|c|c|c|c|c|c|c|}
\hline & \multicolumn{7}{|c|}{ WEIGHT OF ANIMAL IN GRAMG } \\
\hline & 320 & 320 & 285 & 340 & 350 & 255 & 225 \\
\hline Animal number and side..... \{ & $\begin{array}{c}64 \\
\text { Left }\end{array}$ & $\begin{array}{c}\text { B1 } \\
\text { Right }\end{array}$ & $\begin{array}{c}65 \\
\text { Right }\end{array}$ & $\begin{array}{c}66 \\
\text { Right }\end{array}$ & $\begin{array}{l}67 \\
\text { Right }\end{array}$ & $\begin{array}{c}68 \\
\text { Right }\end{array}$ & $\begin{array}{c}69 \\
\text { Right }\end{array}$ \\
\hline 'Vestibular' part. . & 80 & 80 & 73 & 101 & 74 & 105 & 99 \\
\hline 1st half-turn.......... & 314 & 307 & 321 & 329 & 286 & 316 & 287 \\
\hline 2nd half-turn....... & 265 & 269 & 266 & 293 & 271 & 278 & 281 \\
\hline 3rd half-turn........... & 199 & 197 & 192 & 201 & 187 & 200 & 198 \\
\hline 4th half-turn........ & 172 & 175 & 176 & 186 & 169 & 185 & 180 \\
\hline 5th half-turn......... & 156 & 148 & 146 & 152 & 140 & 153 & 148 \\
\hline 6 th half-turn.... & 145 & 143 & 139 & 146 & 134 & 147 & 140 \\
\hline 7th half-turn... & 116 & 114 & 113 & 119 & 108 & 118 & 112 \\
\hline 8th half-turn...... & 83 & 84 & 86 & 98 & 87 & 94 & 88 \\
\hline Apical part........ & 20 & 21 & 31 & 46 & 14 & 30 & 52 \\
\hline
\end{tabular}

average cochlea; so there would be, of course, some slight adjustments necessary in fitting each cochlea to the fixed length, but the gain in facility of comparison might in some cases render it advisable. The original graphic plots can of course be reproduced as either line drawings or halftones.

\section{SUMMARY}

Most observers have reported cochlear injuries by written protocols and midmodiolar section diagrams, making only rough estimates of the relative lengths of various lesions, usually in terms of approximate parts of turns, without evaluation of the lengths of various turns. Better interpretation of results is permitted by 
the author's former method of charting the organ of Corti as a straight band with the relative lengths of the various half-turns approximated, but since the linear value of the several parts of a curved structure contained in radial, oblique, and tangential sections varies, the locations of the ends of lesions were only approximate. The graphic reconstruction method here presented evaluates directly the approximate lengths of all portions of the organ of Corti when cut in serial sections. On ruled paper each space represents a section; the limiting sections for each half-turn are determined and a series of semicircular ares drawn connecting the points thus found; the result is a 'spiral-like' curve making approximate allowance for variations in linear values of different sections. This is the 'base-line' for charting any desired data. The percentages of error for different portions have been determined for six graphs and are recorded.

The more accurate data secured by this new method may be transferred to straight-line charts to facilitate comparison of numerous observations. The method will not only yield more accurate data, but will, if adopted by other workers in this field of investigation, also render the results of all avilable to the others in a form which will permit of more ready comparison than has previously been possible. This would, without question, greatly facilitate the solution of the problem of the physiology of hearing.

The general method may be modified so that other parts of cochlea may also be graphically represented. The demonstration of variation in individual cochlex is a secondary result: 


\section{BIBLIOGRAPHY}

The papers listed are only part of those recording cochlear lesions.

GorLD, S. R. 1919 War deafness and its prevention-Report of the labyrinths of the animals used in testing of preventive measures. Jour. Lab. and Clin. Med.,vol. 4, pp. 153-180.

Hozssu, H. 1912 Weitere experimentelle Studien über die akustische Schädigung des Säugetierlabyrinths. Zeitschr. f. Ohrenheilk., Bd. 64, S. 101-145.

1913 Experimentell erzeugte professionelle Schwerhörigkeit. Ibid., Bd. 69, S. 224-231.

Hoshino, T. 1917 (An experimental study of the pathology of ears injured by sound and a consideration of the physiologic bearing of the results.) Kyoto Igaku Zassi, vol. 14 (97 pages with 63 figures).

ВАтон, N. 1917 Der histologische Bau der Vogelschnecke und ihre Schädigung durch akustische Reize und durch Detonation. Basel.

WitTMAacK, K. 1907 Ǔber Schädigung des Gehörs durch Schalleinwirkung. Zeitschr. f. Ohrenheilk., Bd. 54, S. 37-80.

1909 Zur Frage der Schädigung des Gehörsorgans durch Schalleinwirkung. Ibid., Bd. 59, S. 211-220.

1918 Vergleichende Untersuchungen über Luftschall-Luftsleitungund Bodensehwingung-Korperleitungssehädigungen des akustischen Apparates. Arch. f. Ohrenheilk., Bd. 102, S. 96-107.

YosHII, U. 1909 Experimentelle Untersuchungen über die Schädigung des Gehörsorgan durch Schalleinwirkung. Zeitschr. f. Ohrenheilk., Bd. 58, S. 201-251. 